\title{
Kompresi Sinyal EKG menggunakan Teknik Parameter Extraction
}

\section{CINTHIA ALIWARGA ${ }^{1}$, ALOYSIUS ADYA PRAMUDITA ${ }^{2}$, MARIA ANGELA KARTAWIDJAJA ${ }^{3}$}

\author{
1,3Postgraduate Department of Electrical Engineering, Atma Jaya Catholic University \\ of Indonesia \\ ${ }^{2}$ Dept. of Telecommunication Engineering, Telkom University \\ Email : cinthia_aliwarga@yahoo.com
}

Received 26 Desember 2018 | Revised 9 Januari 2019 | Accepted 24 Maret 2019

\begin{abstract}
ABSTRAK
Sistem healthcare IoT menyebabkan peningkatan trafik komunikasi dan jumlah penyimpanan data. Elektrokardiogram (EKG) adalah salah satu alat yang berperan penting dalam healthcare IoT. Pasien yang mengalami kelainan jantung perlu dipantau oleh EKG dalam periode waktu lama sehingga menghasilkan data dalam jumlah yang sangat besar. Kompresi data mampu menjadi solusi masalah di atas. Penelitian ini melakukan kompresi sinyal EKG menggunakan metode parameter extraction untuk satu sik/us sinyal dari dua belas pasien yang dipilih secara acak. Hasil penelitian menunjukkan bahwa kinerja kompresi baik, ditunjukkan oleh nilai Compression Ratio (CR) 6,24 dan Mean Square Error (MSE) 0,0018 .
\end{abstract}

Kata kunci: IoT, EKG, kompresi data, parameter ekstraction.

\begin{abstract}
Healthcare IOT causing higher data communication traffic and storage. Electrocardiogram (ECG) is one of the important device in healthcare IoT. Patient whose have heart abnormality needs ECG monitoring for long period of time, this causing a big data size. Data compression become one of the solutions for this problem. This research focused on data compression using parameter extraction method for one cycle ECG signal from twelve patients. This research has a good result with Compression Ratio (CR) 6,24 and Mean Square Error (MSE) 0,0018.
\end{abstract}

Keywords: IoT, ECG, data compression, parameter extraction 


\section{PENDAhULUAN}

Sistem healthcare IoT membuat alat-alat kesehatan terhubung ke jaringan dan internet, alatalat ini akan melakukan komunikasi data ke jaringan dalam periode waktu tertentu sehingga membuat peningkatan trafik komunikasi. Data yang dikirimkan oleh alat-alat tersebut juga akan disimpan baik di node perantara maupun di cloud sehingga membuat kebutuhan media penyimpanan meningkat. Elektrokardiogram (EKG) adalah alat yang digunakan untuk merekam pola detak jantung, oleh karena itu EKG merupakan salah satu alat yang memiliki peranan penting dalam healthcare IoT. Untuk hasil diagnosis yang baik EKG menggunakan frekuensi sampling 250-500 Hz dengan resolusi 12 bit pada setiap lead, sehingga besar data menjadi 11-22 Mbit/jam/lead (Zigel, Cohen, \& Katz, 2000). Pasien-pasien yang memiliki kelainan jantung perlu dipantau oleh EKG dalam periode waktu yang lama sehingga menghasilkan data yang sangat besar. Hal ini akan menjadi penghambat pengaplikasian healthcare IoT pada alat EKG. Semakin besar data maka trafik komunikasi semakin tinggi sehingga waktu pengiriman data akan semakin lama, selain itu biaya penyimpanan yang diperlukan juga akan semakin mahal. Kompresi data menjadi salah satu alternatif solusi untuk mengatasi kedua masalah tadi.

Penelitian ini menggunakan teknik kompresi parameter extraction. Sejumlah parameter dari satu siklus denyut jantung dicari melalui proses iterasi dan ditentukan berdasarkan Minimum Mean Square Error (MMSE). Parameter-parameter yang diperoleh kemudian disimpan menjadi satu file dan file tersebut yang rencananya akan dikirimkan ke node perantara atau disimpan di cloud. Penelitian ini merupakan penelitian tahap awal dan mempertimbangkan pola bentuk EKG seseorang umumnya berulang selama periode waktu tertentu, maka penelitian ini menggunakan satu siklus jantung sebagai sample. Kehandalan rekonstruksi sinyal diuji dengan pengambilan data siklus jantung dari record lain. Fitur lain seperti informasi terkait detak jantung dan deteksi penyakit merupakan pengembangan lanjutan dari penelitian ini.

Untuk mengetahui kinerja kompresi digunakan nilai Compression Ratio (CR) dan Mean Square Error (MSE). CR membandingkan besar file yang berisi parameter-parameter dengan besar file berisi data asli, sedangkan MSE menghitung besar perbedaan antara sinyal hasil rekonstruksi dan sinyal asli.

Penelitian ini merupakan penelitian lanjutan dari prosiding pada The $3^{\text {rd }}$ International Conference on Engineering of Tarumanegara (ICET) 2017 (Pramudita, Aliwarga, Sari, \& Kartawidjaja, 2017). Modifikasi dilakukan pada penentuan parameter dominan dan metode penentuan kinerja kompresi. Selain itu dalam penelitian ini kinerja kompresi diuji untuk data pasien yang lebih banyak yaitu dua belas data dibanding penelitian sebelumnya yang menggunakan satu data.

\section{METODOLOGI PENELITIAN}

\subsection{Pengambilan Data Sinyal EKG}

Data sinyal EKG yang akan dikompresi dalam penelitian diperoleh dari MIT/BIH Arrhythmia Database (Goldberger, dkk, 2000). MIT-BIH Arrhythmia Database merupakan kumpulan data EKG dari Beth Israel Hospital Arrhythmia Laboratory. Record 100 sampai 124 pada database ini dipilih secara acak dari keseluruhan data yang tersedia, sedangkan record 200 sampai 234 dipilih untuk menambahkan variasi fenomena penting yang jarang terjadi (Moody, 2010). Sinyal yang digunakan dalam penelitian ini adalah sinyal dari lead MLII. Data diambil secara acak sebanyak dua belas data pasien, dalam penelitian ini digunakan 
data dari record 100, 101, 106, 114, 121, 124, 200, 201, 210, 212, 222 dan 231. Dari setiap record diambil data satu siklus denyut jantung yang digunakan sebagai data masukan untuk kemudian dikompresi.

Langkah pertama yang dilakukan adalah membagi sinyal EKG dalam satu siklus menjadi tiga bagian yaitu bagian P, QRS, dan T. Proses segmentasi diperlukan karena karakteristik setiap bagian berbeda, sehingga parameter yang memiliki pengaruh dominan di setiap bagian juga berbeda. Proses segmentasi dalam penelitian ini dilakukan secara manual untuk menghindari error pada proses peak detection yang menyebabkan kinerja kompresi tidak akurat.

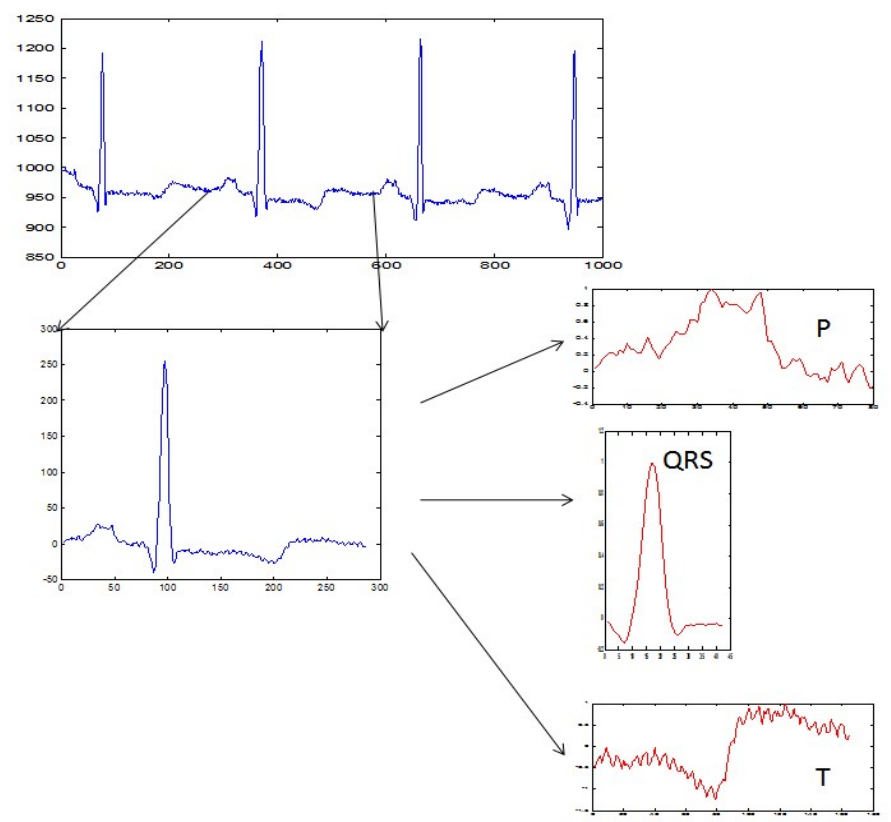

Gambar 1. Contoh Tiga Bagian dari Satu Siklus Sinyal EKG yaitu P, QRS, dan T

\subsection{Parameter Extraction}

Proses parameter extraction bertujuan untuk memperoleh nilai beberapa parameter yang dapat mewakili keseluruhan data sinyal. Nilai parameter-parameter ini yang kemudian akan digunakan dan bukan lagi data asli, sehingga diharapkan besar data menjadi lebih kecil. Langkah awal untuk mencari nilai parameter adalah dengan mengeliminasi komponen DC dari sinyal menggunakan transformasi Fourier. Setelah komponen DC dari setiap bagian sinyal dihilangkan, sinyal dinormalisasi, lalu kemudian dilakukan iterasi untuk pencarian nilai parameter.

Proses iterasi dan rekonstruksi sinyal menggunakan Persamaan (1) yang diperkenalkan oleh Mukhopadhyay dan Sircar (Mukhopadhyay \& Sircar, 1996).

$$
\hat{y}(n)=A e^{\frac{b}{\alpha(1-\cos (\alpha m))}} \cos (k \alpha m+c \pi)
$$

Parameter $A$ mempengaruhi tinggi amplitudo sinyal rekonstruksi tanpa mempengaruhi lebar sinyal. Pengaruh parameter $A$ terhadap bentuk sinyal dapat dilihat pada Gambar 2. 


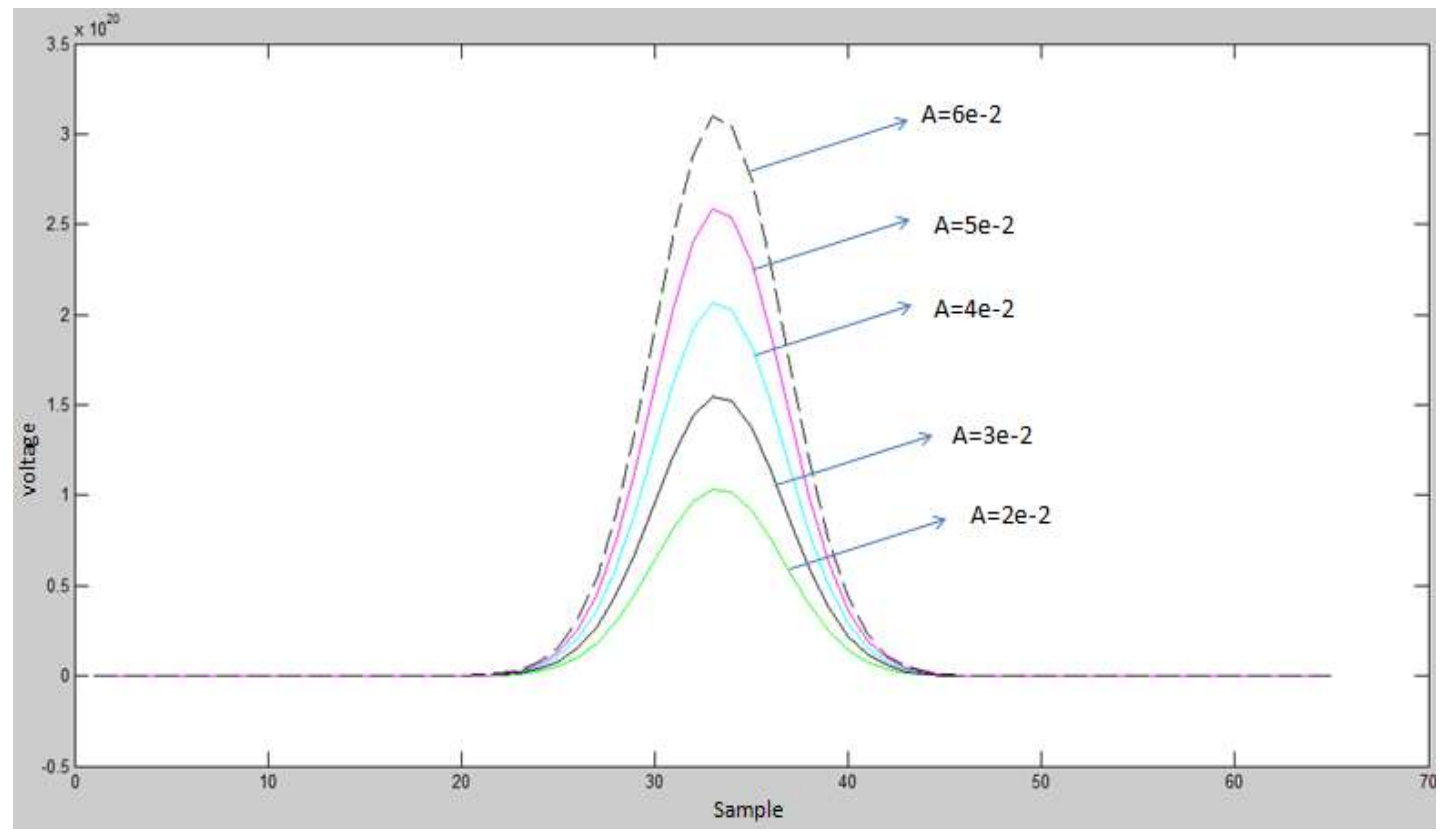

Gambar 2. Pengaruh Parameter A terhadap Bentuk Sinyal

Parameter $k$ mempengaruhi sidelobe sebuah sinyal, semakin tinggi nilai $k$ maka semakin besar pula sidelobe sinyal tersebut dan lebar peak sinyal semakin sempit. Nilai $k$ yang ganjil akan membentuk sinyal menjulang ke atas, sedangkan nilai $k$ yang genap akan membentuk sinyal melengkung ke bawah. Oleh karena sifatnya ini, maka parameter $k$ merupakan parameter dominan pada bagian QRS. Pengaruh parameter $k$ terhadap bentuk sinyal dapat dilihat pada Gambar 3.

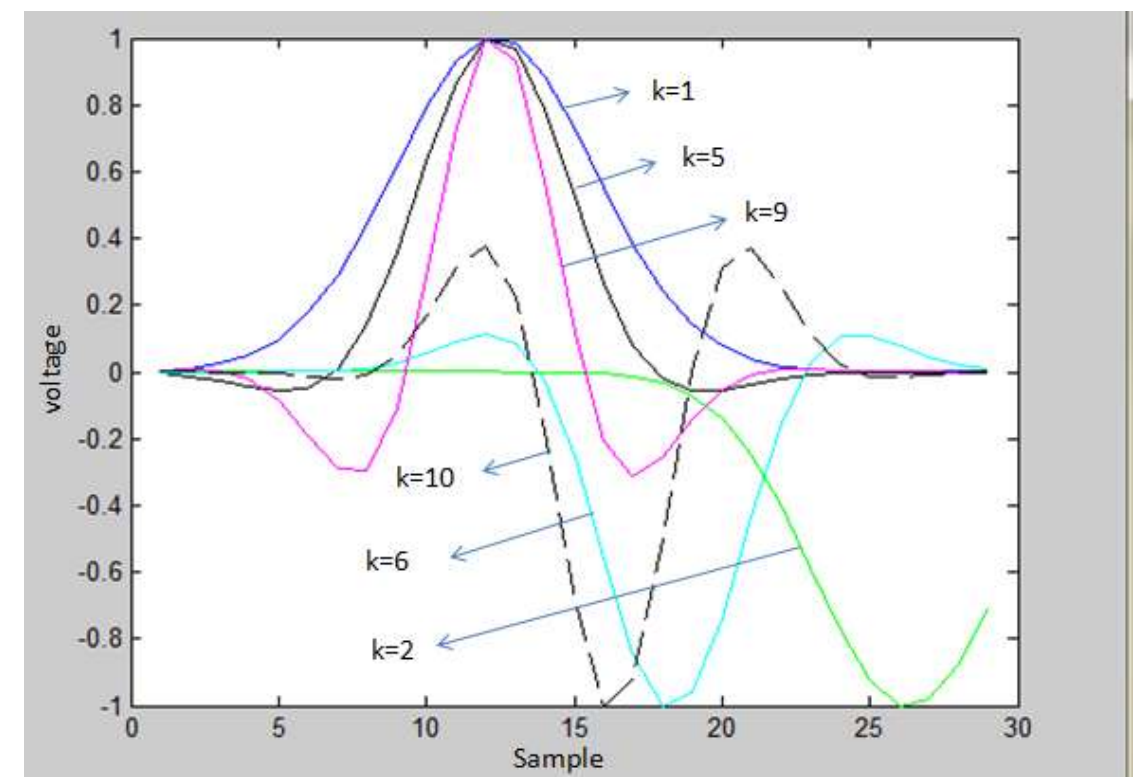

Gambar 3. Pengaruh Parameter k Terhadap Bentuk Sinyal

Parameter $c$ mempengaruhi pergeseran fasa dari sebuah sinyal sehingga parameter ini dominan untuk bagian sinyal $\mathrm{P}$ dan $\mathrm{T}$, selain itu parameter $c$ juga merupakan parameter dominan kedua untuk bagian QRS. Pengaruh parameter $c$ terhadap bentuk sinyal dapat dilihat pada Gambar 4. 


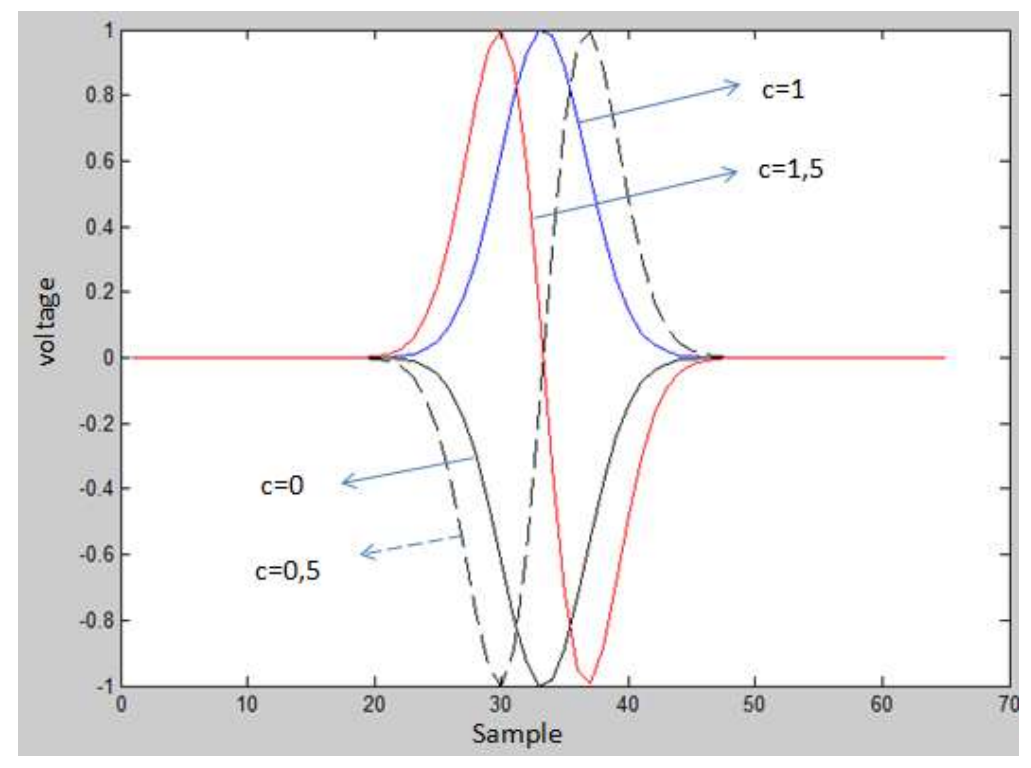

Gambar 4. Pengaruh Parameter c terhadap Bentuk Sinyal

Parameter $b$ mempengaruhi lebar sinyal sehingga secara umum berpengaruh terhadap setiap bagian sinyal dan diiterasi setelah nilai parameter dominan diperoleh. Pengaruh parameter $b$ terhadap bentuk sinyal dapat dilihat pada Gambar 5.

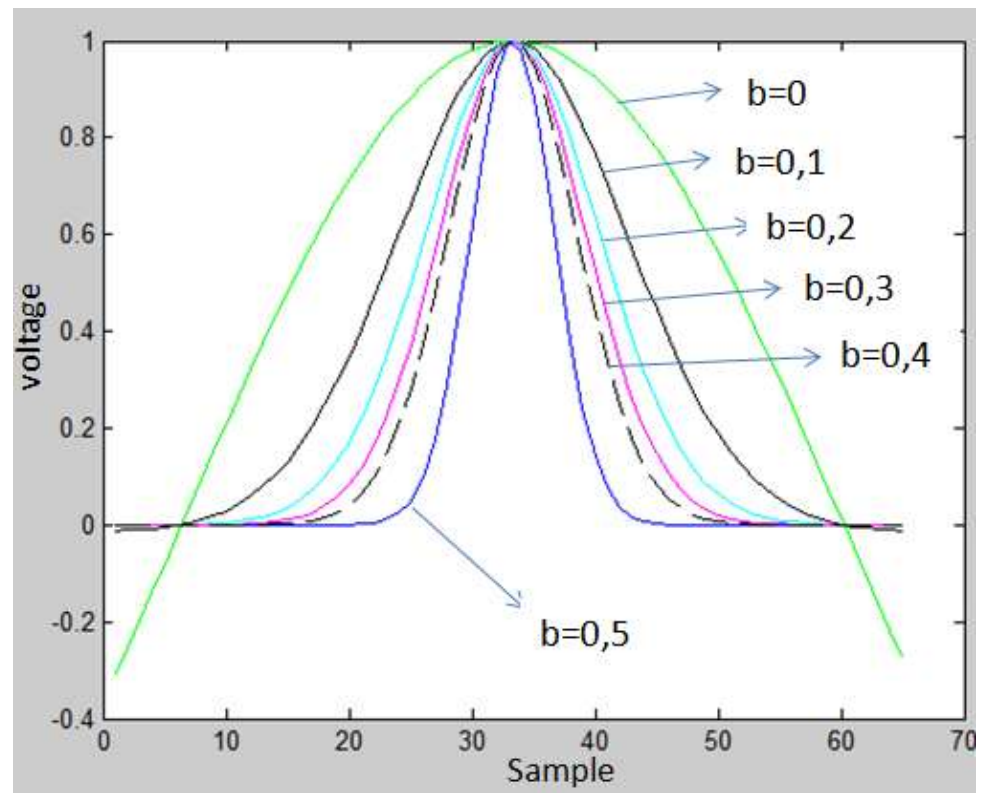

Gambar 5. Pengaruh Parameter b terhadap Bentuk Sinyal

Parameter dominan merupakan parameter yang pertama dilakukan iterasi karena akan membentuk rangka utama dari sebuah sinyal. Urutan iterasi parameter untuk bagian $\mathrm{P}$ dan $\mathrm{T}$ adalah c-b-k sedangkan urutan iterasi parameter untuk bagian QRS adalah k-c-b. Parameter dipilih berdasarkan Minimum Mean Square Error (MMSE) terkecil. Setelah semua parameter dari setiap bagian sinyal ditemukan, dilakukan rekonstruksi sinyal menggunakan Persamaan (1). 


\subsection{Rekonstruksi Sinyal Residual}

Sinyal hasil rekonstruksi berdasarkan parameter masih sedikit berbeda dengan sinyal asli, oleh karena itu dilakukan rekonstruksi sinyal residual agar hasil rekonstruksi yang diperoleh semakin mendekati sinyal asli. Langkah awal untuk menghasilkan sinyal residual dimulai dengan melakukan pengurangan antara sinyal asli dan sinyal hasil rekonstruksi berdasarkan parameter. Pengurangan dilakukan terpisah untuk setiap bagian dari sinyal EKG. Selisih tersebut kemudian dimodelkan menggunakan metode Auto Regressive (AR) Yule-Walker orde empat sehingga menghasilkan lima koefisien AR. Sinyal residual kemudian dibentuk menggunakan filter dengan koefisien AR sebagai koefisien filter. Setelah sinyal residual dari setiap bagian diperoleh, sinyal tersebut kemudian dijumlahkan dengan sinyal hasil rekonstruksi parameter dan diperoleh sinyal rekonstruksi yang akan digunakan.

\subsection{Evaluasi Kinerja Kompresi}

Kinerja kompresi dievaluasi dengan menghitung nilai Compression Ratio (CR) dan Mean Square Error (MSE) yang masing-masing dihitung menggunakan Persamaan (2) dan Persamaan (3). Tujuan dari kompresi data ECG adalah untuk memperoleh nilai CR yang tinggi. Namun kinerja kompresi tidak bisa dikatakan baik hanya dengan CR yang tinggi saja, kualitas sinyal rekonstruksi juga tetap harus diperhatikan (Blanco-Velasco et al., 2005). CR digunakan untuk menghitung besar kompresi data dengan membandingkan besar data asli dan besar data hasil rekonstruksi.

$$
C R=\frac{B_{o}}{B_{C}}
$$

$\mathrm{B}_{0}$ merupakan besar data asli dan $\mathrm{B}_{\mathrm{c}}$ merupakan besar data kumpulan parameter. Kedua data disimpan dalam file dengan format .mat. Format .mat yang digunakan dalam penelitian ini menonaktifkan proses kompresi yang secara default diaplikasikan oleh Matlab R2013a.

Mean Square Error (MSE) dapat menjadi tolak ukur untuk menilai kualitas sinyal hasil rekonstruksi. MSE mengukur perbedaan antara sinyal asli dan sinyal hasil rekonstruksi. Jika diperoleh nilai MSE yang kecil maka kinerja kompresi semakin baik. Menurut penelitian yang dilakukan oleh Nemcova et al. (Němcová, Smíšek, Maršánová, Smital, \& Vítek, 2018) MSE merupakan salah satu metode yang direkomendasikan untuk menilai kualifikasi sinyal EKG. MSE dapat dikategorikan kecil apabila nilai yang diperoleh di bawah 0,025 (Fong, Mittu, Ratwani, \& Reggia, 2014). MSE dirumuskan dengan Persamaan (3).

$$
M S E=\frac{1}{N} \sum_{n=1}^{N}[x(n)-\widetilde{x}(n)]^{2}
$$

Dengan $\mathrm{N}$ adalah jumlah data, $\mathrm{x}(\mathrm{n})$ adalah data asli dan $\widetilde{x}(\mathrm{n})$ adalah data hasil rekonstruksi.

\section{HASIL DAN PEMBAHASAN}

Persamaan (1) yang diaplikasikan untuk metode kompresi ditujukan untuk pola EKG yang bervariasi sehingga dapat digunakan tidak hanya untuk EKG normal. Perbedaan pola dapat dilihat dari perbedaan nilai parameter-parameter yang diperoleh dari penelitian. Nilai parameter-parameter yang diperoleh dari proses parameter extraction untuk dua belas record dapat dilihat pada Tabel 1. 
Tabel 1. Nilai Parameter-Parameter yang dihasilkan Proses Parameter Extraction

\begin{tabular}{|c|c|c|c|c|c|c|c|c|c|c|c|c|}
\hline \multirow[b]{2}{*}{ DATA } & \multicolumn{4}{|c|}{$\mathbf{P}$} & \multicolumn{4}{|c|}{ QRS } & \multicolumn{4}{|c|}{$T$} \\
\hline & A & b & c & k & A & b & c & k & A & b & c & $\mathbf{k}$ \\
\hline record 100 & 17,620 & 0,38 & 1,48 & 1 & 244,620 & 0,86 & 1 & 7 & 26,380 & 0,49 & 0,52 & 1 \\
\hline record 101 & 22,359 & 0,92 & 1,48 & 1 & 285,359 & 1,04 & 1,01 & 5 & 34,641 & 1,28 & 0,52 & 1 \\
\hline record 106 & 44,813 & 0,46 & 0,98 & 1 & 261,187 & 0,4 & 1,2 & 1 & 96,187 & 1,26 & 0,54 & 1 \\
\hline record 114 & 21,551 & 0,2 & 1,18 & 1 & 399,551 & 1,2 & 1,31 & 1 & 55,551 & 0,72 & 0,52 & 1 \\
\hline record 121 & 33,438 & 0 & 1,48 & 1 & 168,562 & 1,1 & 1,13 & 5 & 17,438 & 0,57 & 1,46 & 1 \\
\hline record 124 & 62,407 & 0,64 & 0,54 & 1 & 391,407 & 0,8 & 1 & 5 & 71,593 & 0,76 & 0,5 & 1 \\
\hline record 200 & 40,453 & 0,94 & 0,82 & 1 & 372,453 & 0,32 & 1,16 & 1 & 103,547 & 0,29 & 1,96 & 1 \\
\hline record 201 & 31,740 & 0,24 & 1,12 & 1 & 189,260 & 1,18 & 1,04 & 3 & 22,740 & 0,97 & 1,48 & 1 \\
\hline record 210 & 10,019 & 0 & 0,5 & 1 & 219,981 & 0,24 & 1,11 & 1 & 45,019 & 0,67 & 1,5 & 1 \\
\hline record 212 & 38,371 & 0,84 & 1,48 & 3 & 344,629 & 2,5 & 1,06 & 7 & 35,371 & 0,48 & 1,5 & 1 \\
\hline record 222 & 39,301 & 0,8 & 1,46 & 1 & 160,301 & 1,14 & 1,06 & 7 & 15,699 & 0,85 & 1,48 & 1 \\
\hline record 231 & 40,033 & 0,54 & 1,04 & 1 & 319,967 & 0,36 & 1,18 & 5 & 65,967 & 0,75 & 1,48 & 1 \\
\hline
\end{tabular}

Koefisien AR yang diperoleh dan digunakan untuk menghasilkan sinyal residual dapat dilihat pada Tabel 2, Tabel 3, dan Tabel 4.

Tabel 2. Nilai Lima Koefisien AR dari Bagian P yang diperoleh dalam Penelitian

\begin{tabular}{|l|c|c|c|c|c|}
\hline \multicolumn{1}{|c|}{ DATA } & \multicolumn{5}{c|}{ AR } \\
\hline Record 100 & 1 & $-1,103$ & 0,222 & 0,201 & $-0,192$ \\
\hline Record 101 & 1 & $-1,097$ & 0,283 & 0,087 & $-0,168$ \\
\hline Record 106 & 1 & $-1,053$ & 0,190 & 0,254 & $-0,272$ \\
\hline Record 114 & 1 & $-1,080$ & 0,392 & 0,100 & $-0,320$ \\
\hline Record 121 & 1 & $-1,014$ & $-0,122$ & 0,192 & 0,013 \\
\hline Record 124 & 1 & $-1,524$ & 0,769 & $-0,076$ & 0,084 \\
\hline Record 200 & 1 & $-0,898$ & 0,057 & 0,009 & $-0,116$ \\
\hline Record 201 & 1 & $-1,015$ & $-0,071$ & 0,363 & $-0,155$ \\
\hline Record 210 & 1 & $-0,910$ & 0,163 & 0,333 & $-0,524$ \\
\hline Record 212 & 1 & $-1,128$ & 0,110 & 0,106 & $-0,047$ \\
\hline Record 222 & 1 & $-1,035$ & $-0,040$ & 0,120 & 0,044 \\
\hline Record 231 & 1 & $-0,93$ & $-0,15$ & 0,18 & 0,022 \\
\hline
\end{tabular}


Tabel 3. Nilai Lima Koefisien AR dari Bagian QRS yang diperoleh dalam Penelitian

\begin{tabular}{|l|l|l|l|l|l|}
\hline \multicolumn{1}{|c|}{ DATA } & \multicolumn{5}{c|}{ AR QRs } \\
\hline Record 100 & 1 & $-1,447$ & 0,794 & $-0,002$ & $-0,127$ \\
\hline Record 101 & 1 & $-1,267$ & 0,522 & $-0,045$ & 0,039 \\
\hline Record 106 & 1 & $-1,425$ & 0,652 & 0,244 & $-0,234$ \\
\hline Record 114 & 1 & $-1,186$ & 0,332 & 0,180 & $-0,097$ \\
\hline Record 121 & 1 & $-1,089$ & 0,068 & $-0,001$ & 0,088 \\
\hline Record 124 & 1 & $-1,340$ & 0,287 & 0,240 & $-0,044$ \\
\hline Record 200 & 1 & $-0,924$ & 0,168 & 0,058 & 0,050 \\
\hline Record 201 & 1 & $-1,500$ & 0,673 & 0,121 & $-0,175$ \\
\hline Record 210 & 1 & $-1,096$ & 0,084 & 0,643 & $-0,268$ \\
\hline Record 212 & 1 & $-1,528$ & 0,782 & 0,144 & $-0,343$ \\
\hline Record 222 & 1 & $-1,211$ & 0,491 & 0,084 & $-0,281$ \\
\hline Record 231 & 1 & $-1,26$ & 0,396 & 0,015 & 0,066 \\
\hline
\end{tabular}

Tabel 4. Nilai Lima Koefisien AR dari Bagian T yang diperoleh dalam Penelitian

\begin{tabular}{|l|c|c|c|c|c|}
\hline \multicolumn{1}{|c|}{ DATA } & \multicolumn{5}{c|}{ AR $_{\mathbf{T}}$} \\
\hline Record 100 & 1 & $-0,801$ & 0,045 & 0,098 & $-0,268$ \\
\hline Record 101 & 1 & $-1,079$ & 0,210 & 0,078 & $-0,187$ \\
\hline Record 106 & 1 & $-1,284$ & 0,392 & 0,079 & $-0,177$ \\
\hline Record 114 & 1 & $-0,759$ & 0,026 & 0,021 & $-0,237$ \\
\hline Record 121 & 1 & $-0,895$ & 0,054 & $-0,020$ & 0,015 \\
\hline Record 124 & 1 & $-0,979$ & $-0,123$ & 0,127 & 0,039 \\
\hline Record 200 & 1 & $-0,708$ & $-0,012$ & $-0,067$ & $-0,112$ \\
\hline Record 201 & 1 & $-1,310$ & 0,569 & $-0,087$ & $-0,125$ \\
\hline Record 210 & 1 & $-1,079$ & 0,070 & 0,252 & $-0,227$ \\
\hline Record 212 & 1 & $-1,104$ & 0,251 & 0,236 & $-0,295$ \\
\hline Record 222 & 1 & $-0,831$ & 0,149 & 0,309 & $-0,392$ \\
\hline Record 231 & 1 & $-0,98$ & $-0,06$ & 0,014 & 0,051 \\
\hline
\end{tabular}


Hasil penelitian berupa besar Compression Ratio (CR) dan Mean Square Error (MSE) dapat dilihat pada Tabel 5.

Tabel 5. CR dan MSE yang diperoleh dari Penelitian

\begin{tabular}{|l|c|c|}
\hline \multicolumn{1}{|c|}{ Data } & CR & MSE \\
\hline record $100 \mathrm{~m}$ & 7,33 & 0,0008 \\
\hline record $101 \mathrm{~m}$ & 6,47 & 0,0006 \\
\hline record $106 \mathrm{~m}$ & 6,47 & 0,0026 \\
\hline record $114 \mathrm{~m}$ & 7,09 & 0,0010 \\
\hline record $121 \mathrm{~m}$ & 7,21 & 0,0006 \\
\hline record $124 \mathrm{~m}$ & 6,25 & 0,0017 \\
\hline record $200 \mathrm{~m}$ & 7,09 & 0,0013 \\
\hline record $201 \mathrm{~m}$ & 4,75 & 0,0010 \\
\hline record $210 \mathrm{~m}$ & 6,35 & 0,0022 \\
\hline record $212 \mathrm{~m}$ & 5,74 & 0,0009 \\
\hline record $222 \mathrm{~m}$ & 4,12 & 0,0018 \\
\hline record $231 \mathrm{~m}$ & 5,98 & 0,0074 \\
\hline Rata-rata & 6,24 & 0,0018 \\
\hline
\end{tabular}

Gambar 6 menunjukkan contoh perbandingan antara sinyal asli dengan sinyal hasil rekonstruksi parameter. Sedangkan Gambar 7 menunjukkan sinyal rekonstruksi yang sudah ditambahkan dengan sinyal residual dibandingkan dengan sinyal asli. Dari kedua gambar tersebut dapat dilihat perbedaan dan fungsi penambahan sinyal residual yaitu membuat sinyal rekonstruksi semakin menyerupai sinyal asli.

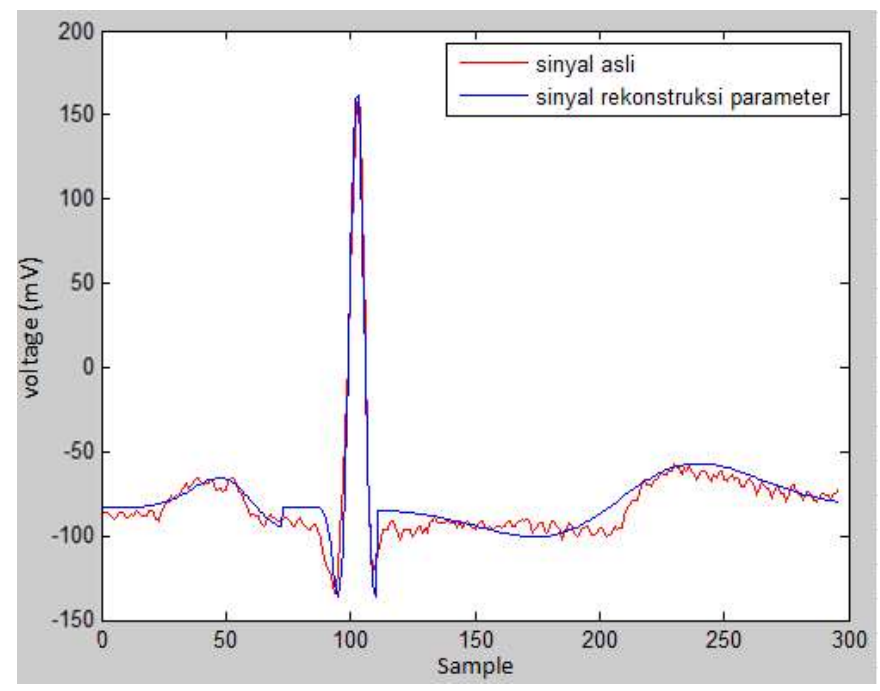

Gambar 6. Perbandingan Sinyal Asli dan Sinyal Rekonstruksi Parameter Record 100

Perbandingan bentuk sinyal asli dan sinyal hasil rekonstruksi untuk setiap data dapat dilihat pada Gambar 7 sampai dengan Gambar 18. 


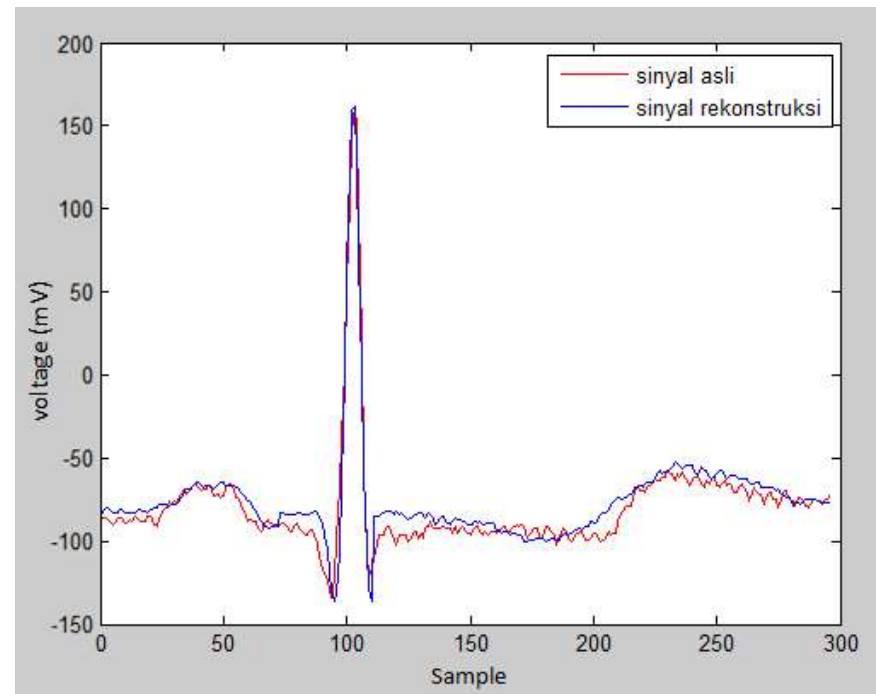

Gambar 7. Perbandingan Sinyal Asli dan Rekonstruksi Record 100

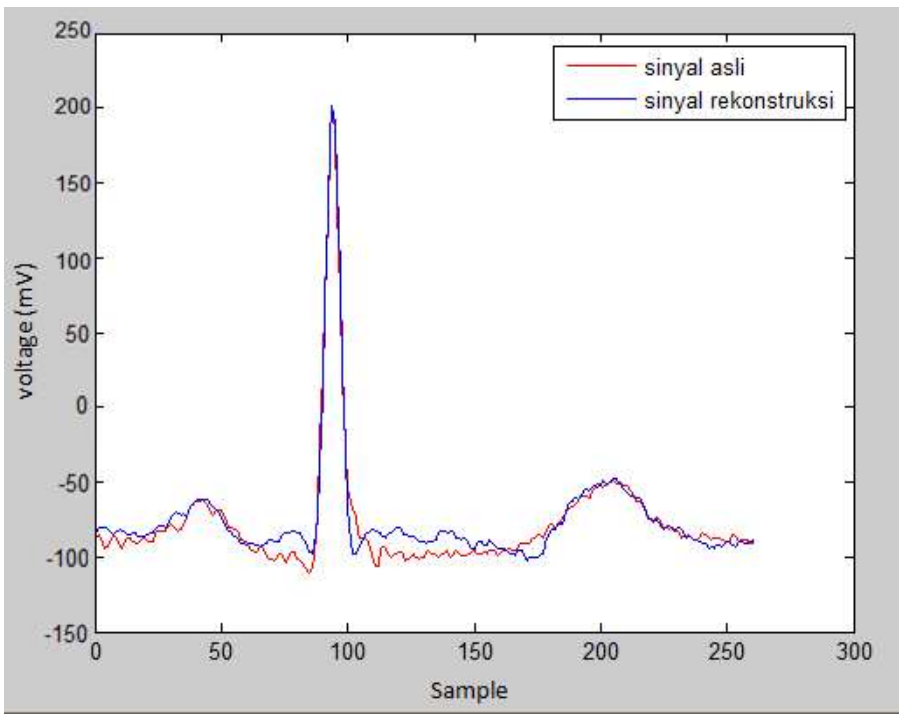

Gambar 8. Perbandingan Sinyal Asli dan Rekonstruksi Record 101

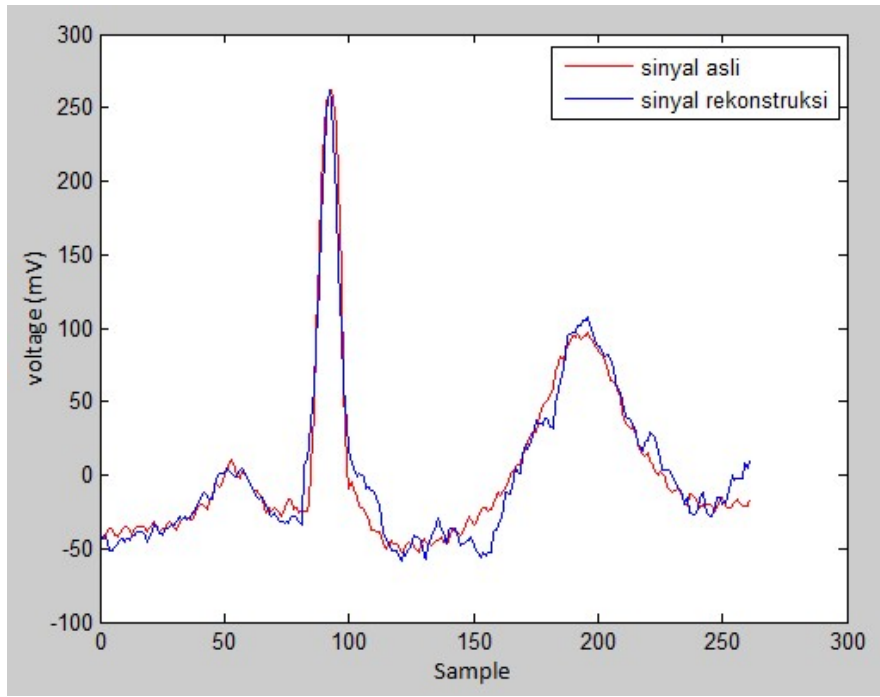

Gambar 9. Perbandingan Sinyal Asli dan Rekonstruksi Record 106 


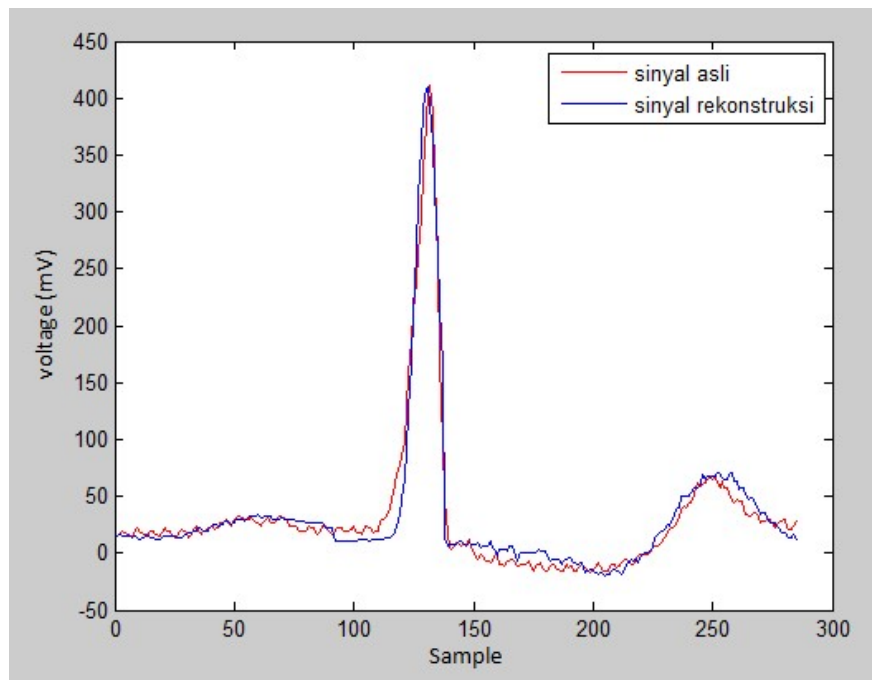

Gambar 10. Perbandingan Sinyal Asli dan Rekonstruksi Record 114

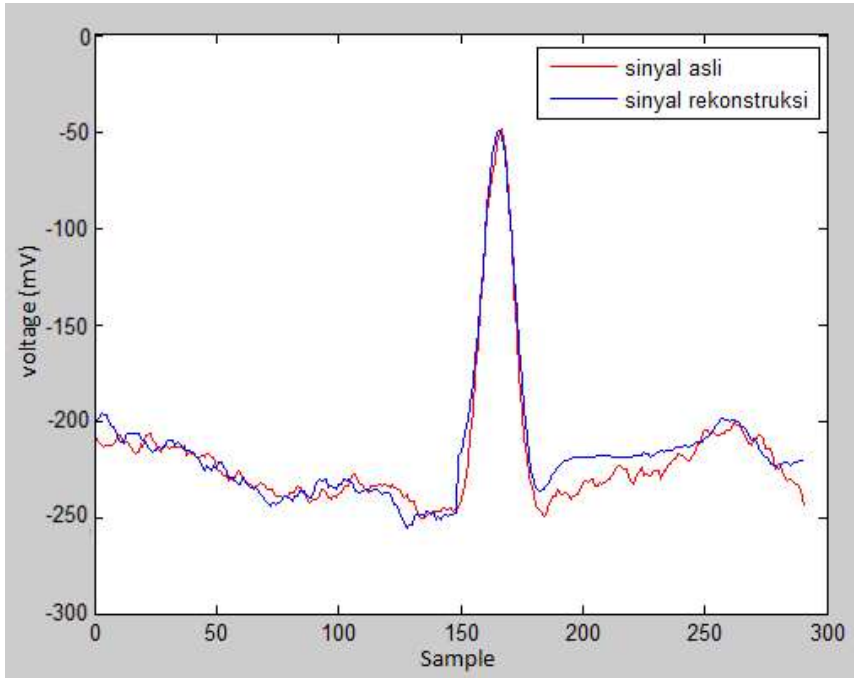

Gambar 11. Perbandingan Sinyal Asli dan Rekonstruksi Record 121

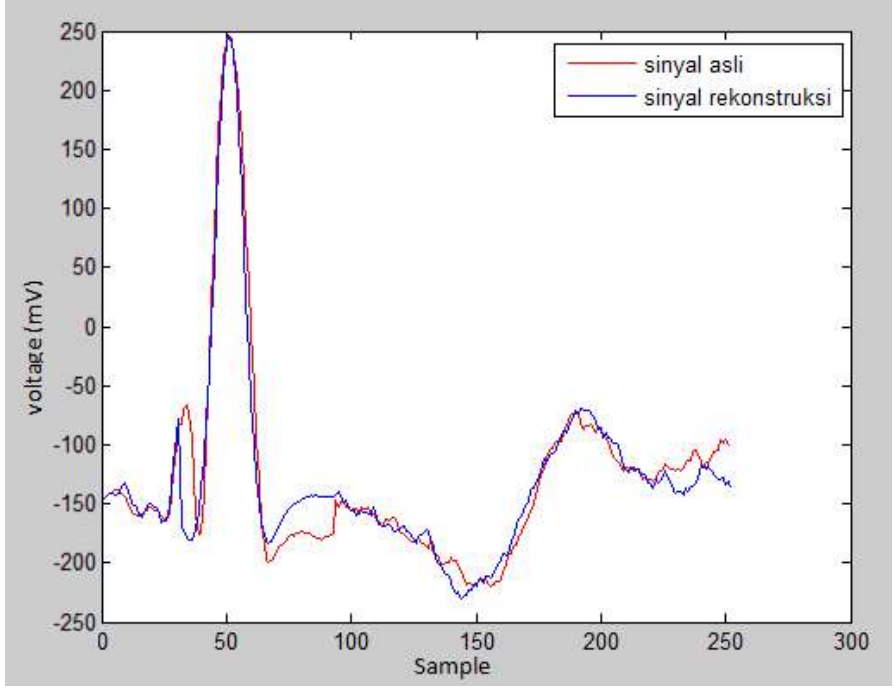

Gambar 12. Perbandingan Sinyal Asli dan Rekonstruksi Record 124 


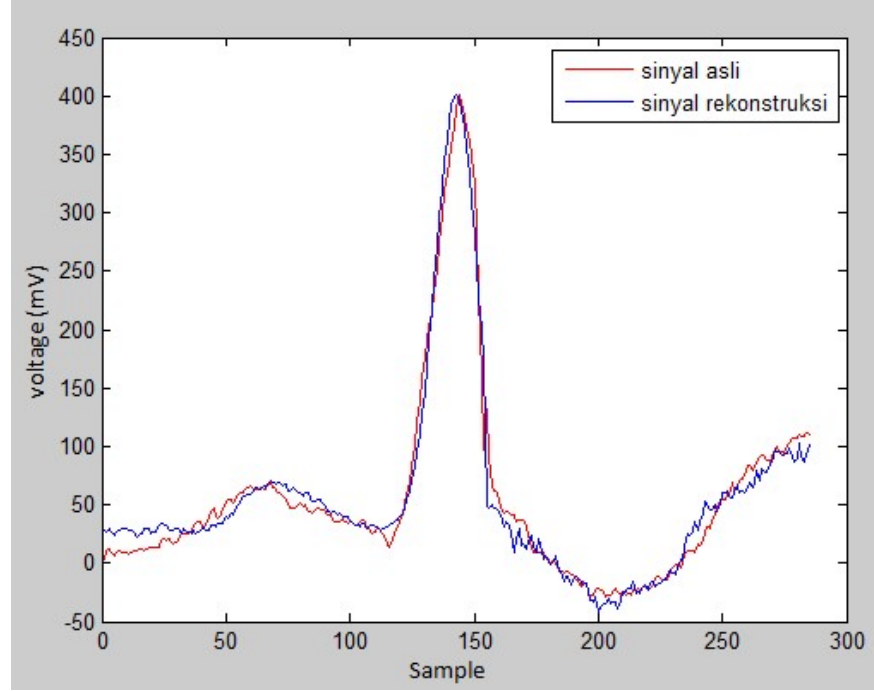

Gambar 13. Perbandingan Sinyal Asli dan Rekonstruksi Record 200

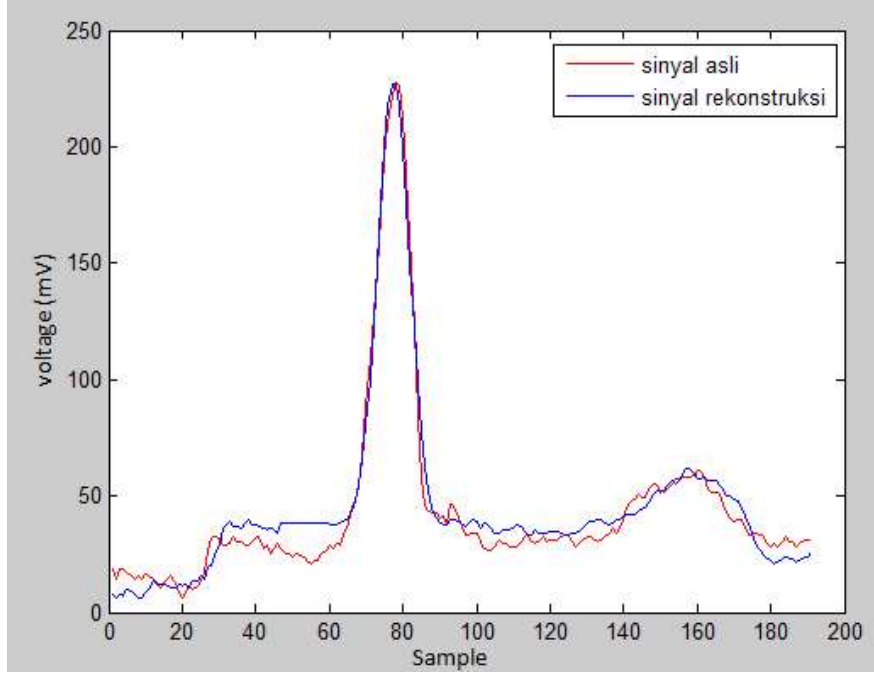

Gambar 14. Perbandingan Sinyal Asli dan Rekonstruksi Record 201

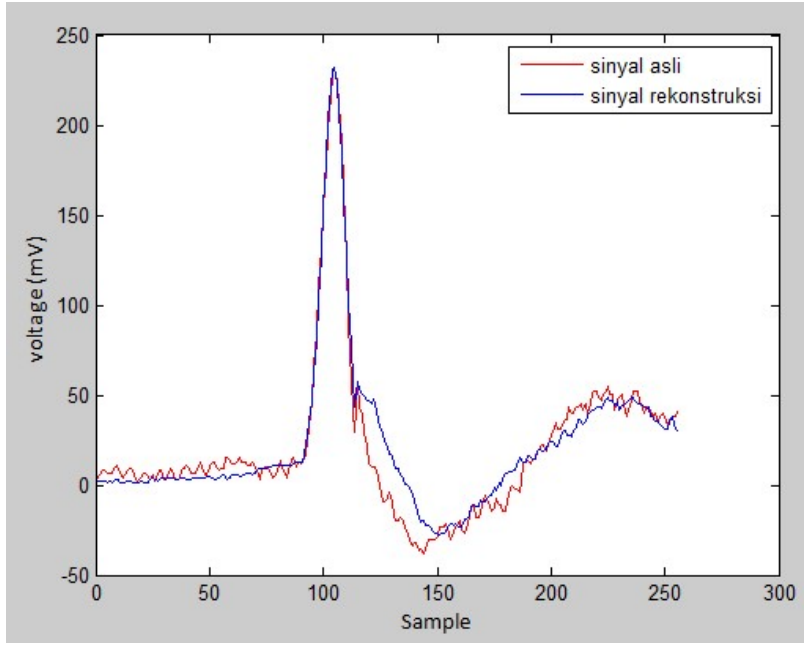

Gambar 15. Perbandingan Sinyal Asli dan Rekonstruksi Record 210 


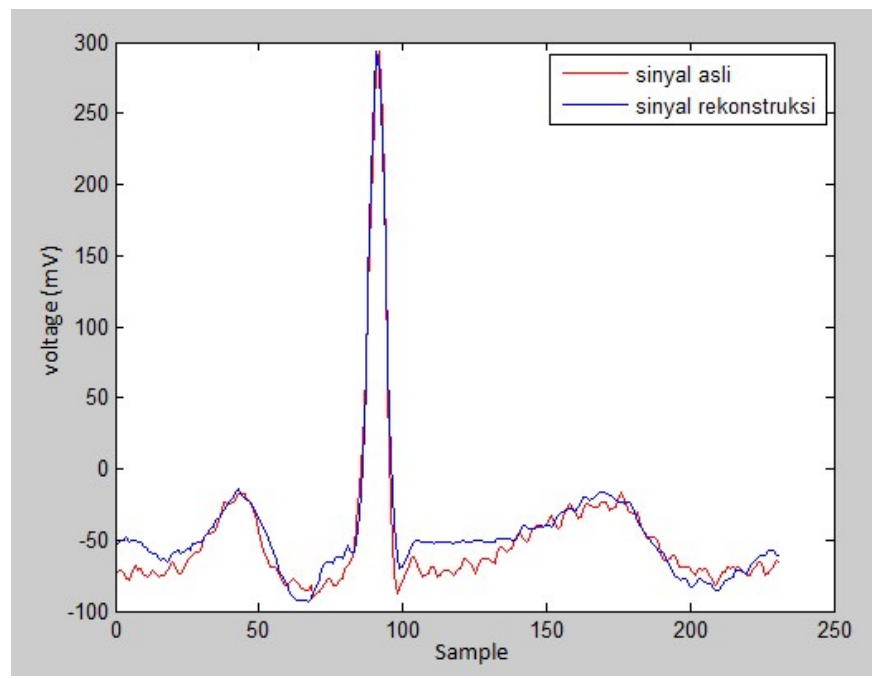

Gambar 16. Perbandingan Sinyal Asli dan Rekonstruksi Record 212

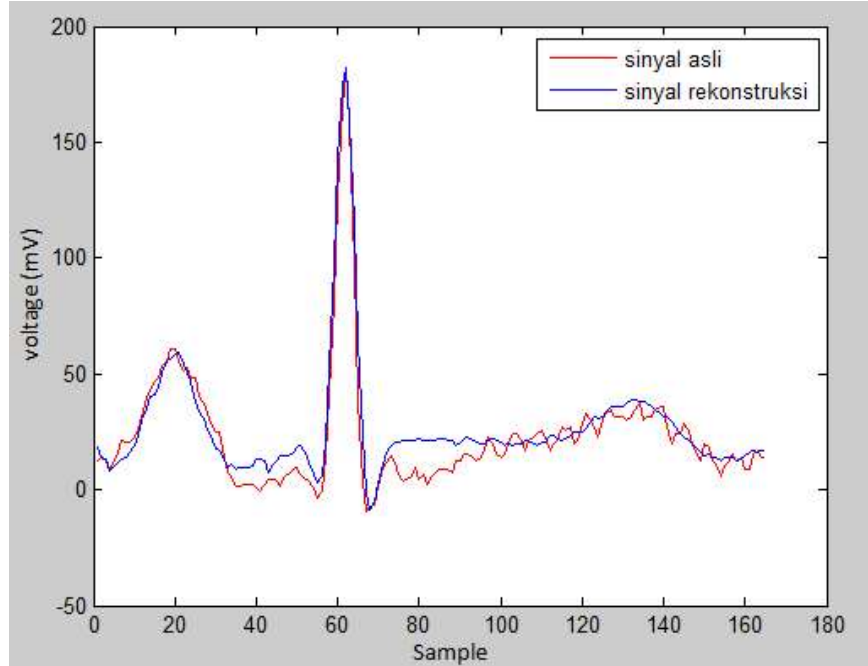

Gambar 17. Perbandingan Sinyal Asli dan Rekonstruksi Record 222

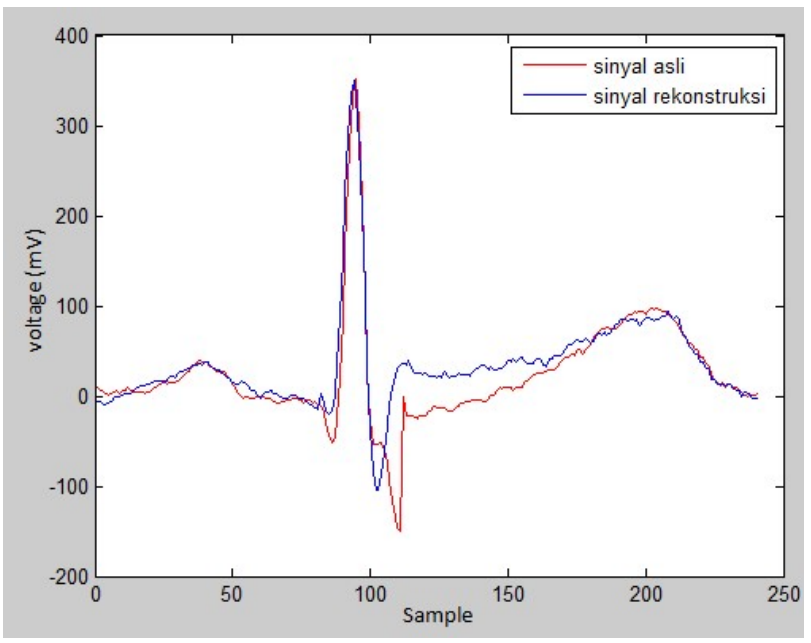

Gambar 18. Perbandingan Sinyal Asli dan Rekonstruksi Record 231 
Nilai CR yang diperoleh dari penelitian memiliki nilai rata-rata sebesar 6,24. Nilai ini menunjukkan bahwa ukuran data kompresi menjadi 6,24 kali lebih kecil dari ukuran data semula. Jika dibandingkan dengan beberapa penelitian sebelumnya (Singh, Kaur, \& Singh, 2015) nilai CR 6,24 lebih besar dari 28 persen penelitian yang dicantumkan pada publikasi tersebut, sehingga dapat dikatakan nilai CR yang diperoleh cukup baik. Besar data kumpulan parameter $\left(B_{c}\right)$ untuk setiap siklus jantung yang diteliti sama dikarenakan jumlah parameter yang disimpan sama. Oleh karena itu, perbedaan besar nilai CR dari setiap record dipengaruhi oleh besar data asli untuk membentuk satu siklus jantung $\left(B_{0}\right)$. Nilai $C R$ yang diperoleh dari record 201 dan 222 lebih kecil dibanding record lain karena detak jantung terjadi dalam periode yang lebih singkat sehingga jumlah data untuk satu siklus detak jantung menjadi lebih sedikit dibanding record lain.

Nilai CR yang cukup besar ini akan berkontribusi untuk memperkecil kebutuhan media penyimpanan data. Untuk satu siklus detak jantung rata-rata besar datanya adalah 2033 bytes, dan setelah dikompresi menjadi 326 bytes. Detak jantung manusia normal usia dewasa dalam keadaan rileks adalah 60-100 bpm (Mishra \& Rath, 2011). Jika diasumsikan dengan detak jantung 80 bpm maka besar data tanpa kompresi untuk satu jam adalah sebesar 9,3 MB, sedangkan besar data dengan kompresi hanya sebesar 1,49 MB. Hal ini tentu saja memberi keuntungan dalam pengaplikasian IoT karena pada umumnya data dari banyak alat EKG akan disimpan dahulu dalam media penyimpanan yang terbatas di suatu node sebelum dikirimkan ke internet. Juga hal ini akan berpengaruh terhadap besar server atau cloud yang akan digunakan, sehingga akan menghemat biaya penyimpanan data.

Nilai CR yang besar juga berkontribusi terhadap kecepatan pengiriman data. CR yang besar berarti data dapat dikompresi menjadi ukuran yang jauh lebih kecil sehingga data mampu dikirimkan lebih cepat. Semakin cepat proses pengiriman data memberi dampak positif bagi pengaplikasian IoT karena apabila terjadi situasi kritis maka waktu tanggap akan lebih cepat. Meski kecepatan rekonstruksi data juga berpengaruh terhadap waktu tanggap, namun dalam penelitian ini diabaikan dengan pertimbangan permasalahan tersebut dapat diminimalisir dengan semakin majunya teknologi komputasi.

Kinerja kompresi tidak dapat dikatakan baik hanya dengan CR yang tinggi saja, kualitas sinyal rekonstruksi juga tetap harus diperhatikan (Blanco-Velasco et al., 2005), oleh karena itu MSE digunakan sebagai tolak ukur untuk menilai kualitas sinyal rekonstruksi. Semakin besar selisih antara sinyal asli dan sinyal hasil rekonstruksi maka semakin besar nilai MSE. Rata-rata nilai MSE yang diperoleh dari percobaan adalah 0,0018. Nilai ini baik karena berada di bawah 0,025 (Fong et al., 2014).

Berdasarkan nilai CR dan MSE yang diperoleh dari penelitian, dapat dikatakan kompresi menggunakan metode parameter extraction berdasarkan Persamaan (1) memiliki kinerja kompresi yang baik. Nilai CR yang diperoleh cukup besar yaitu 6,24 dan nilai MSE yang kecil yaitu 0,0018 .

\section{KESIMPULAN}

Penelitian kompresi sinyal menggunakan metode parameter extraction dengan dasar persamaan yang dibuat oleh Mukhopadhyay dan Sircar memberikan hasil CR yang cukup baik dengan rata-rata 6,24, atau dengan kata lain data dapat diperkecil sampai 6,24 kali. Nilai CR yang besar memberi solusi permasalahan dalam pengaplikasian IoT karena mampu memberikan efisiensi dalam hal penyimpanan data dan kecepatan pengiriman data. Namun 
nilai CR saja tidak cukup untuk mengukur kinerja kompresi karena kualitas sinyal rekonstruksi tetap harus diperhatikan, oleh karena itu nilai MSE dihitung sebagai tolak ukur kualitas sinyal. MSE yang diperoleh dari penelitian baik dengan nilai rata-rata 0,0018. Berdasarkan nilai CR dan MSE yang diperoleh dari penelitian, dapat dikatakan kompresi menggunakan metode parameter extraction yang dilakukan pada penelitian ini memiliki kinerja kompresi yang baik untuk satu siklus sinyal EKG.

\section{DAFTAR RUJUKAN}

Blanco-Velasco, M., Cruz-Roldán, F., Godino-Llorente, J. I., Blanco-Velasco, J., ArmiensAparicio, C., \& López-Ferreras, F. (2005). On the use of PRD and CR parameters for ECG compression. Medical Engineering and Physics, 279), 798-802. https://doi.org/10.1016/j.medengphy.2005.02.007

Fong, A., Mittu, R., Ratwani, R., \& Reggia, J. (2014). Predicting electrocardiogram and arterial blood pressure waveforms with different Echo State Network architectures. AMIA ... Annual Symposium Proceedings. AMIA Symposium, (pp. 544-553). https://doi.org/10.1016/j.bica.2013.07.005

Goldberger, A. L., Amaral, L. A. N., Glass, L., Hausdorff, J. M., Ivanov, P. C., Mark, R. G., Mietus, J. E., Moody, G. B., Peng, C. K., Stanley, H. E., (2000). PhysioBank, PhysioToolkit, and PhysioNet: Components of a New Research Resource for Complex Physiologic Signals. Retrived from https://physionet.org/cgi-bin/atm/ATM.

Mishra, T. K., \& Rath, P. K. (2011). Pivotal role of heart rate in health and disease. Journal, Indian Academy of Clinical Medicine, 12(4), 297-302.

Moody, G.B., (2010). MIT-BIH Arrhythmia Database Introduction. Retrived from https://physionet.org/physiobank/database/html/mitdbdir/intro.htm

Mukhopadhyay, S., \& Sircar, P. (1996). Parametric modelling of ECG signal. Medical and Biological Engineering and Computing, 34(2), 171-174. https://doi.org/10.1007/BF02520024

Němcová, A., Smíšek, R., Maršánová, L., Smital, L., \& Vítek, M. (2018). A comparative analysis of methods for evaluation of ECG signal quality after compression. BioMed Research International, 2018. https://doi.org/10.1155/2018/1868519

Pramudita, A. A., Aliwarga, C., Sari, L., \& Kartawidjaja, M. A., (2017). ECG signal model parameters extraction method for data compression. $3^{\text {rd }}$ International Conference on Engineering of Tarumanegara (ICET) : Smart Engineering for Future Cities, Universtias Tarumanegara. Jakarta : Faculty of Engineering Universtias Tarumanegara 
Singh, B., Kaur, A., \& Singh, J. (2015). A Review of ECG Data Compression Techniques. International Journal of Computer Applications, 116(11), 975-8887. https://doi.org/10.2307/1435861

Zigel, Y., Cohen, A., \& Katz, A. (2000). ECG signal compression using analysis by synthesis coding. IEEE Transactions on Biomedical Engineering, 4Л10), 1308-1316. https://doi.org/10.1109/10.871403 